\title{
INTAKE AND NUTRIENT DIGESTIBILITIES OF ALL-CONCENTRATE DIET FROM FORAGE AND SOME CROP WASTES BY SHEEP AND GOATS
}

\author{
t. A. ADELOYE \\ Departmeni of Agricultural Science \\ Adeyemi College of Education \\ Ondo, Nigeria
}

Received 13 February, 1992 Accpted 7 January, 1993

\begin{abstract}
A total of 20 animals comprising 10 rams and 10 bucks were involved in a digestibility study to assess the nutritive value of a combination of yam peel, cocoa-seed testa and Leucaena leaf in an all-concentrate diet for the sheep and goat. Parameters for assessment were dry matter intakes, dry matter and nutrient digestibilities, total digestible nutrients and nutritive ratio. The dry matter intakes in the all-concentrate diet by the sheep and goat ( $>4 \%$ of body weight) were higher $(p<0.05)$ than obtained for the conventional diet of grass hay and supplemental concentrate. The digestibilities of dry matter, crude fibre and energy were lower $(\mathrm{P}<0.05)$ while those of crude protein and ether extract were higher and significant when compared to the conventional diet. The nature of the crude fibre of all- concentrate feed could influence the dry matter and energy digestibilities, and the digestible energy. The nutritive ratio of the all-concentrate feed was narrow $(P<0.05)$ and indicated a high nutritive value.
\end{abstract}

Key words: Yam peels, cocoa seed testa, Leucaena leaf meal, digestibilities, sheep and goat.

\section{INTRODUCTION}

Agricultural wastes from crops in the rural, sub-urban and industrial settlements have often constituted health hazards due to inade-

Present Address: Department of Atimal Production, University of llorin, P. M. B. 1515, Ilorin, Nigeria.

Nigerian Journal of Animal Production 20 (1993) quate means of disposal. Yam peel is obtained by peeling the yam tuber for processing (boiling or frying) for human consumption. The peel is light and fairly tough when properly dried. Cocoa seed testa (CSI) is an industrial by-product in the processing of cocoa. It has a pleasant smell. These by-products are relished by sheep and goats which scavenge in the localities. The wastes appear fibrous in nature but could be suitable for the ruminants if the intake and utilization are improved.

forage legumes form an important part of the dict of small ruminants particularly in the rural and sub-urban settlements (Akinsoyinu and Onwuka, 1988). Their roles as protein supplement (PANESA, 1989) and "improvers" of the feeding values of crop residues have been documented (Le Houerou, 1980; Onwuka, 1986; Keftasa, 1987; Pancsa, 1989). binda and Ayoade (1985 and 1986) have reported improvement in feed intake and feed digestibility from the addition of Leucaena kucocephala leaves to maize stover-diets of malawian goats. This study makes a nutritive evaluation of a diet compounded from yam peel, cocoa seed testa and Leucaena leacocephala leaf meal fed as sole source of nutrient to the sheep and goat.

\section{MATERIALS AND METHODS}

Twenty adult male West African dwarf (WAD) sheep and goats approximately 18 months of agc and weighing $19-23 \mathrm{~kg}$ were dipped against ectoparasites and dewormed of endoparasites. The two animal species were 
randomized into 2 groups each, consisting of 5 WAD sheep or 5 WAD goats. They were immediately transferred each to individual metabolism crates suitably constructed for the comfort of the animals.

The crop wastes including the forage legume were all collected in Southern Nigeria. Yam peels were collected from the catering department of a High School in Ondo. The cocoa seed testa was obtained from the Cocoa Processing Industry at Ile-Oluji. Young Leucaena leaves were harvested from the Teaching and Research Farm of Obafemi Awolowo University, Ile-Ife. The yam peels were sun-dried on concrete slab for 14 sunny days while the Leucaena leaves were air-dried in bunches for 21 days. Both were ground to pass through a $3 \mathrm{~mm}$ sievc. The experimental diet was formulated as presented in Table 1.

The animals were fed for a preliminary period of 14 days to adjust to confinement and to normalise feed intake. $2 \mathrm{~kg}$ of the feed was offered to each animal daily along with fresh water which was provided $a d l i b$. The control diet was made up of one part of concentrate supplement (Table 1) and two parts of hay made from grass (Cynodon nlemfuensis). Feed refusals were collected and weighed on the following day to determine intakes. On day 14 , the animals were each fitted with harness bags for the collection of faeces. The total faeces collected was dried at $80^{\circ} \mathrm{C}$ for 48 hours. It was weighed, milled to pass through a $1 \mathrm{~mm}$ sieve and stored for analysis. Urine was collected in $5 \mathrm{ml}$ acetic acid $(5 \% \mathrm{v} / \mathrm{v})$, the volume was measured and $10 \%$ aliquot preserved at $-4^{\circ} \mathrm{C}$. The collection lasted 7 days. The animals were weighed weekly during the 21 days experimental period.

\section{Chemical analysis}

The experimental feed and faeces were analyzed for the proximate components by the AOAC (1975) methods. The energy contents of the feed, faeces and urine were determined by bomb calorimetry.

\section{Statistics}

The data were subjected to analysis of variance (Steel and Torrie, 1980) and means tested (Duncan, 1955).

\section{RESULTS AND DISCUSSION}

The nature of the diets is as presented in Table 1. The Leucaena leaf meal was the chief source of nitrogen. The inclusion of the leaf meal at $40.5 \%$ (Glasby, 1975) of the total ration (Table 1) was due to its content of mimosine. The yam peel and cocoa-seed testa were included as sources of the required energy in the experimental diet. The weight balances for all the animals were positive.

The value of any forage feed whether mixed or not is determined by its acceptability and digestibility by the animals. These are evaluated with the assumption that if intake is enhanced, a combination of the crop wastes with the legume forage is likely to improve the production of sheep and goats due to higher nutritive valuc. The data on dry matter intakes (Table 2) were pooled for each group of the animals as the differences observed in the replicates werc not significant $(P>0.05)$. The control and experimental diets were well accepted as the dry matter intakes in all the treatments were more than $3.0 \%$ of body weight (Olubajo and Oyenuga, 1974). However, for the two animal species, the dry matter intakes of the experimental diet were apparently $(\mathrm{P}<0.05)$ higher than those of the control, thus manifesting a better acceptability of the all-concentrate diet over the conventional diet.

The dry matter digestibilities of the sheep and goats on the experimental diet were lower $(\mathrm{P}<0.05)$ than the control's. The same trends were observed with the crude fibre and energy digestibilities. The findings are suggestive, on the one hand, of the nature of the experimental diet with regard to the crude fibre and, on the other hand, explains a 
Table 1. COMPOSITION OF DIETS

\begin{tabular}{lclc}
\hline Control (supplement) & & Experimental & \\
\hline Ingredient & $\%$ Composition & Ingredicnt & \% Composition \\
\hline Yellow maize & 75 & Yam pecl & 20.5 \\
Groundnut cake & 20 & $\begin{array}{l}\text { Cocoa seed } \\
\text { testa }\end{array}$ & 31.0 \\
Wheat offals & 2.5 & $\begin{array}{l}\text { I.cucaena } \\
\text { leaf meal }\end{array}$ & 40.5 \\
Salt & 0.5 & $\begin{array}{l}\text { Groundnut } \\
\text { cake }\end{array}$ & 6.0 \\
Vitamin/mineral & 1.0 & Urea & 1.0 \\
mixture & 1.0 & Salt & 0.5 \\
Dicalcium phosphate & & $\begin{array}{l}\text { Dicalcium } \\
\text { phosphate }\end{array}$ & 0.5 \\
& 100 & Total & 100.00
\end{tabular}

Analyzed components:

( $1 / 3$ supplement

$+2 / 3$ grasshay).

(all-concentrate)

Dry matter (DM)

On dry matter basis

89.4

91.3

crude protein

14.3

24.8

crude fibre

21.1

16.9

ether extract

2.3

5.9

NFE

55.0

44.3

total ash

7.3

8.1

energy (Kcal/g DM)

4.7

4.2 

Table 2. DRY MATTER INTAKE, WEIGHT CHANGES, NUTRIENT DIGESTIBILITY AND ENERGY
VALUES FOR SOME CROP WASTES FED TO SHEEP AND GOATS

\section{Control}

Experimental

\begin{tabular}{llll} 
Sheep & Goat & Sheep & Goat \\
\hline
\end{tabular}

Feed intake

Dry matter intake $(\mathrm{g} / \mathrm{d})$

Dry matter intake (\% of body weight)

Weight changes $\mathrm{kg}$

Initial liveweight

Final liveweight

Weight gain

$\begin{array}{lrrr}804.0 & 709.3 & 882.5 & 950.8 \\ 4.00^{\mathrm{h}} & 4.19^{\mathrm{h}} & 4.48^{\mathrm{a}} & 4.53^{\mathrm{a}}\end{array}$

$\begin{array}{cccc}a & a & b & b \\ 20 \pm 1.7 & 19.1 \pm 1.4 & 19.5 \pm 1.0 & 19 \pm 0.9 \\ 20.6 \pm 1.8 & 19.7 \pm 1.4 & 20 \pm 0.9 & 19.5 \pm 1.1 \\ 0.6 & 0.6 & 0.5 & 0.5\end{array}$

Nutrient digestibility

Dry matter

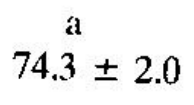

$$
\stackrel{a}{a}+1.9
$$

$\stackrel{\stackrel{b}{ }}{61.5} \pm 2.5$

b

Crude protein

$50.2^{b} \pm 2.0$

b

$57.2 \pm 2.4$

a

$58.1 \pm 2.6$

$56.0 \pm 1.2$

Crude fibre

$\stackrel{\mathrm{a}}{57.5} \pm 2$.

a

$59.6 \pm 2.6$

b

$24.3 \pm 4.7$

b

$60.7 \pm 1.3$

Ether Extract ${ }^{2}$

b

$65.4 \pm 2.0$

b

$$
\begin{gathered}
b \\
65.0
\end{gathered}
$$

$95.6^{a} \pm 0.3$

$20.5 \pm 2.1$

Nitrogen free extract

$66.1^{a} \pm 2.1$

$\mathrm{ab}$

$64.5 \pm 1.7$

bc

$59.7 \pm 2.5$

$\stackrel{a}{95.4} \pm 2.1$

Energy

$\stackrel{\text { a }}{68.4} \pm 1.8$

$\stackrel{\text { a }}{66.1} \pm 2.4$

b

$59.2 \pm 7.7$

b

Energy value (Kcal/gDM)

Digestible energy (DE)

Metabolizable energy (ME)

$3.2^{\mathrm{a}}$

ME as \% of gross energy

Total Digestible nutrients

Nutritive ratio

$\begin{array}{cc}3.2^{\mathrm{a}} & 3.1^{\mathrm{a}} \\ 2.6^{\mathrm{a}} & 2.5^{\mathrm{a}} \\ 55.7 & 55.0 \\ 59.0^{\mathrm{bc}} & 56.9^{\mathrm{c}} \\ 7.2^{\mathrm{a}} & 7.0^{\mathrm{a}}\end{array}$

$2.5^{\mathrm{b}}$
$2.0^{\mathrm{b}}$
$48.6^{\mathrm{a}}$
$62.5^{\mathrm{a}}$
$3.3^{\mathrm{b}}$

$2.4^{\mathrm{b}}$

$2.0^{\mathrm{b}}$

47.0

$60.3^{\text {ab }}$

$3.3^{\mathrm{b}}$

$3.3^{\text {b }}$ 
possible relationship between the digestibilities of dry matter, crude fibre and energy. In the 2 groups of animals, the crude protein and ether extract were better digested $(P<0.05)$ in the experimental diet than the control. No definite pattern could be established for the total digestible nutrients for the 2 groups of animals. The narrow nutritive ratio of the experimental diet attests to the high nutritive value of the all-concentrate feed as obtained from the high crude protein digestibility.

\section{REFERENCES}

AKINSOYINU, A. O. and ONWUKA, C. F.I. (1988) Mineral constituents of some browse plants used in ruminant feeding in southern Nigeria. Nigerian Journal of Animal Production 15: 57-62

A. O. A. C.(1975) Association of Official Analytical Chemists. Official Methods of Analysis 12 th edition. Washington, D.C.

BANDA, L. L. J.and AYOADE, J. A. (1986) Leucaena leaf hay (Leucaena leucocephala cv. Peru) as protein supplement for Malawian goats fed chopped maize stover In: T. R. Preston and M. Y. Nuwanyakpa (eds). Towards option feeding of agricultural by-products to livestock in Africa. Processings of workshop Oct. 1985 Alexandria (Fgypt) p. 124-128.

BANDA, L. L. J. and AYOADE, J. A.(1985) Leucaena leucocephala cv Peru leaf hay as a protein supplement for goats fed chopped maize stover. Leucaena Research Reports (USA) 6 p. 65.

DUNCAN, D. B.(1955) Multiple range and multiple F-tests. Biometrics 11: 1-42.
GLASBY, J. (1975) Encyclopedia of the Alkaloids. Plenum Press, New York, London, I, p. 189 II, 966.

KEFTASA, D. (1987) Role of crop residues as livestock feed in Ethiopian highlands. Processings of the third workshop on African forage plant genetic resources, evaluation of forage germplasm and extensive livestock production systems. Arusha, Tanxaria, April 1987.

Le IIOUEROU, H. N. (1980). Chemical composition and nutritive value of browse in tropical West Africa. In: Le Houcro, H. N. (cd.) Browse in Africa pp. 261-289 (II CA:Addis Ababa).

OIJBAJO, F. O. and OYENUGA. V. A. (1974). The yield, intake and animal production of four tropical grass species grown at Ibadan. Nigerian Journal of Animal Production 1 (2): 217 224.

ONWUKA, C. F. I. (1986) Gliricidia sepium as dry season feed for goat production in Nigeria. Proceedings of the workshop on potential of forage legumes in sub. Saharan Africa, ILCA,Ethiopia pp. $533+539$.

PANESA, (1989). Pasture Nelwork for Eastern and Southern African. International Livestock Centre for Africa, Addis, Ababa, Ethiopia No.9, March 1989. pp. 6-7.

SIEEI, R. G. D. and TORRIE, J. II. 1980. Principles and Procedures of Statistics. A Biometrical Approach. 2nd End. (McGraw-hill: New York). 